\title{
Tanggapan Organisasi Global Mengenai Kasus Pelanggaran HAM Terhadap Kaum Minoritas Etnis Rohingya
}

\author{
Muhammad Ilmiyanor \\ Prodi Pendidikan IPS / Fakultas Keguruan dan Ilmu Pendidikan / ULM
}

\begin{abstract}
The issue of a Human Rights Violation against the Rohingya Ethnic Minority in Myanmar has captured the attention of the world public, including ASEAN and the United Nations itself has also participated in responding to the problem. This issue is about human rights violations in that scope and has something to do with the International Criminal Court. The method used in this article uses Literature Studies through Google Scholar by reviewing several available online journals. The result of this discussion is that as an ASEAN member country, it is time for Myanmar to submit to the ASEAN Charter which has been mutually agreed upon. This dispute resolution effort is carried out by the United Nations as an umbrella for international dispute resolution, namely through resolutions of the United Nations Security Council and the United Nations General Assembly. The ICC exercises its jurisdiction as a form of resolving its Rohingya cases, namely applying its 4 jurisdictions, namely, First, Second Personal Jurisdiction, and Material Jurisdiction. Third, Temporal Jurisdiction and fourth, Territorial Jurisdiction.
\end{abstract}

Key word: Human Rights Violation, Rohingya ethnicity, ASEAN, UN, ICC

\section{Pendahuluan}

Terkait dalam pembahasan Hak Asasi Manusia di wilayah Asia. terdapat kabar mengenai suatu kabar di wilayah Myanmar dalam suatu permasalahan yang amat penting dan merujuk kembali membawa Myanmar kepada suatu masalah terkait Kasus permasalahan Hak Asasi Manusia yang ada indikasi pemerintah Myanmar masih melakukan suatu hal yang melanggar HAM atas etnis Rohingya. Menurut dari Sejarah pada kondisi dan situasi bebasnya penerima nobel yang berkaitan dengan perdamaian Aung San Suu Kyi serta masuknya Suu Kyi dalam suatu Parlemen, Myamnar membangkitkan suatu keinginan khususnya bagi warga minoritas Rohingya yang terus tertindas. dalam hal ini mereka menginginkan Suu Kyi dengan lantang akan berbica terhadap hak para kaum Rohingya tersebut. PBB menyebu kaum yang disebut sebagai kaum minoritas yang paling teraniaya di dunia. Namun, ternyata Suu Kyi pun masih 
mengindari isu tersebut. Misanya pada terjadi kala itu saat Suu Kyi berbincang di Jenewa, Suu Kyi terlihat menanggapinya seperti tidak ada masalah yang begitu besar denngan tidak ada keinginan menyinggung dari rezmi Myamnar sendiri ( Dewa Gede S M, 2012: 4).

PBB atau Perserikatan Bangsa-Bangsa dan kawasan negara Barat, dilihat nampaknya tidak terlalu risih dengan pemberitaan tentang Pelanggaran HAM mengenai pembantaian kepada etnis muslim Rohingya tersebut. Bahkan lebihnya dari pemimpin negara yang mempunyai penduduk yang beragama islam terbanyak di dunia, termasuk indonesia juga turut tutup mata mengenai permasalahan tersebut. Kementrian Luar Negeri menanggapi permasalahan tersebut sebagai suatu permasalahan internal Myanmar. dalam hal ini kasus yang terjadi di Myanmar mengenai kaum Rohingya memang bukan soal terkait agama dan ditindas bukan karena memegang keyakinan soal beragama islam. tetapi, karena etnis Rohingya tidak di anggap satu etnis di Myanmar. Menurut dari pemerintahan Myanmar mengenai etnis Rohingya tersebut dianggap warga tanpa adanya status Kewarganegaraan. Mengenai suatu pembahasan terkait dengan isu-isu hak asasi manusia telah menjadi suatu perhatian dunia dan mengancamnya disentegrasi antar negara maju dengan negara-negara berkembang sebagai dari sebab akibar konfrontasi pandangan Utara sampai Selaran selama pada dekade tahun 1960 an sampai awal 1980 an. Pada masa Perang Dunia kedua (World War II) dan pada era setelah perang, semakin menginginkan dikurangi yuridiksi eksklusif negara atas pada warganya yang berada pada satu pihak, dan lembaga internasional perlindungan bagi individu dalam mengahadapi negara mengenai dimana ia menjadi masyarakat atau warganya di pihak yang lain. Lembaga perlindung tersebut lalu telah dikenal sebagai hak-hak asasi manusia.

Hukum humaniter dulu dikenal dengan hukum perang (Law of War), kemudian menjadi hukum konflik bersenjata (Law of Armed Conflict) dan berubah menjadi Hukum Humaniter Internasional(International Humanitarian Law). (Haryonomataram, 2005:24). Menurut KGPH. Haryonomataram yang diartikan dengan hukum humaniter adalah seperangkat aturan yang didasarkan atas perjanjian internasional dan kebiasaan internasional yang membatasi kekuasaan pihak yang berperang dalam menggunakan cara dan alat berperang untuk mengalahkan musuh dan mengatur perlindungan perang (Haryonomataram, 2005:24). Hukum humaniter mencoba untuk mengatur agar perang 
dapat dilakukan dengan lebih memperhatikan prinsip-prinsip kemanusiaan (Haryonomataram, 2005:25) Hukum Humaniter Internasional berkaitan erat dengan HAM, keduanya menyakut hak perlindungan dan adanya keberadaan manusia yang harus dijaga dan dilindungi bila terkait adanya ancaman kekerasan dan pelanggaran yang terjadi pada manusia ketika peperangan terjadi. Hak-hak tersebut disesuaikan dengan mengutamakan perlindungan hak asasi manusia (Supriyadi, 2013:178). Hak asasi manusia adalah seperangkat gagasan dasar tentang perlakuan yang berhak diterima semua orang karena menjadi manusia (Carlsnaes, 2013:905). Permasalahan mengenai pelanggaran HAM bersangkutan dengan keberadaan Mahkamah Pidana Internasional, yang juga merupakan pedoman dan menelaah persoalan mengenai penegakan keadilan dalam menanggulangi kejahatan internasional khususnya kejahatan Genosida yang melanggar HAM.

ICC merupakan suatu badan peradilan pidana internasional yang bersifat tetap, yang mempunyai kekuasaan untuk melaksanakan yurisdiksinya atas seseorang atau badan hukum yang telah melakukan kejahatan-kejahatan serius yang dikutuk oleh masyarakat internasional (the most serious crimes of concern to the international community). ICC merupakan suatu yang dibutuhkan oleh masyarakat internasional.yang disebutkan sebagai "the missing link in the international legal system".

\section{Metode}

Dalam pembahasan yang dimaksud pada artikel ini bersifat deskriptif. dalam artikel itu ditulis dengan menggunakan Studi Literatur dapat diartikan dalam memahami suatu sistem aktivitas berhubungan dengan pengumpulan data-data yang digunakan berpedoman pada sumber pustaka, mentatat, membaca, sampai membuat bahan yang dikumpulkan dari sumber sekunder ( Snyder, 2019). dalam proses pencarian sumbernya menggunakan beberapa sumber melalui Google dan Google Scholar terkait dari jurnaljurnal online yang tersedia.

\section{Hasil dan Pembahasan}

\section{Pelanggaran HAM terhadap Etnis Rohingya}

Kelompok Etnis Rohinya merupakan kelompok etnis yang berasal dari Bangladesh, namun telah bermukim di negara wilayah Rangkaing di Myanmar sejak abad ke-7 Masehi. Meskupun telah beradab-abad lama bertinggal di Myanmar, 
dalamhal ini pemerintahan Myanmar menyikapinya menggangap bahwa etnis Rohingya termasuk dalam etnis Bengali sehingga tidak dapat diakui sebagai satu diantaranya etnis Myanmar. Hilangnya status kewarganegaraan membuat etnis Rohingya tidak mendapatkan perlindungan dari negara atau nasional. Etnis Rohingya mengalami beragam pelanggaran merujuk pada hak asasi manusia, baik terkait berkewarganegaraan hingga ha beragamapun. Pelanggaran Hak Asasi Manusia inilah yang jadinya mendorong etinis Rohingya untuk meninggalkan Myanmar dan mencari perlindungan di negara lainnya. Beberapa dari mereka pun sampai di Indonesia (Dita Liliansa;2013). Banyak pendapat berbeda yang menjelaskan sejarah Etnis Rohingnya. Rohingnya berasal dari kata Rohan, nama kuno dari Arakan. Rohingnya adalah nama kelompok etnis yang tinggal di negara bagian Arakan/Rakhine sejak abad ke 7 Masehi. Nenek moyang Rohingnya adalah berasal dari campuran Arab, Turki, Persia, Afghanistan, Bengali dan IndoMongoloid. Etnis Rohingnya tersebut melakukan perkawinan sehingga meningkat prosentase kelahirannya.

Populasi orang Rohingnya saat ini sekitar 1.5 juta 3 juta jiwa (Thontowi, 2013:8). Berbagai bentuk tindak pelanggaran HAM terhadap etnis Rohingnya antara lain tindakan genosida sejak 1978 dengan tujuan untuk mengusir keberadaan mereka dari wilayah Myanmar. Hak kebebasan untuk bergerak (freedom to movement) bagi orang-orang Rohingnya dibatasi secara ketat dan sebagian besar dari mereka tidak diakui sebagai warga negara Myanmar, melainkan sebagai imigran ilegal. Pada tahun 1978, terjadi pula operasi militer masif, yang dikenal dengan nama Operasi Naga Min (Dragon King) untuk menghilangkan imigran ilegal, bahkan pada tahun 2012, sejak terjadinya konflik 10-28 Juni 2012 sedikitnya 650 warga etnis Rohingnya tewas, sekitar 1200 warga dinyatakan hilang, dan 50 ribu warga kehilangan tempat tinggal.

Etnis Rohingnya yang mengalami tindakan diskriminasi berupa penyiksaan dan kekerasan yang tidak manusiawi, membuat negara harus bertanggung jawab dengan melakukan penyelidikan atas kasus pembunuhan Etnis Rohingnya dengan secara tranparan dan jujur untuk dapat mengadili dan menghukum pelakupelaku tersebut. Eskalasi konflik di Rakhine kembali terjadi. Sejak 1982, ketika Jenderal Ne Wing mengeluarkan kebijakan segregasi warga negara, orangorang Rohingnya sudah terdiskriminasi dan mengalami persekusi. Selain terancam genosida, mereka pun tidak mendapatkan hak selayaknya warga negara. 


\section{Pelanggaran HAM Terhadap Etnis Rohingya persfektif PBB}

Rentetan kekerasan terhadap muslim Rohingnya pada dasarnya sudah memenuhi definisi untuk disebut pembersihan etnis dalam pengertian Konvensi Perserikatan BangsaBangsa 1948 tentang genosida. Pasal 2 konvensi menyatakan genosida berarti perbuatan dengan tujuan menghancurkan,baik keseluruhan maupun sebagian, sebuah bangsa, etnis, ras, dan kelompok agama dengan cara membunuh atau membatasi hakhak dan kebebasan mereka. Adapun usaha dan upaya penyelesaian sengketa ini yang dilakukan oleh PBB sebagai payung penyelesaian sengketa internasional yaitu melalui resolusi Dewan Keamanan PBB dan Majelis Umum PBB. Namun, dalam kasus krisis Rohingnya di Rakhine, PBB secara kelembagaan hanya mengeluarkan dua kali resolusi sebagai berikut ;

Pertama, resolusi Dewan Keamanan PBB bernomor S/2007/14 pada 12 Januari 2007 dan kedua, resolusi Dewan HAM PBB tentang tim pencari fakta atas konflik Rakhine pada 26 Maret 2017. Meski PBB mengirim tim pencari fakta pada Januari 2017 setelah eskalasi konflik pada 2016, tetapi dua resolusi PBB itu belum berhasil memecahkan persoalan. Banyak hambatan dalam pelaksanaan resolusi. PBB mengeluarkan resolusi dimana resolusi ini menyatakan kutukan terhadap pemerintah juga militer Myanmar atas terjadinya percobaan pemusnahan etnis di negara bagian Arakan, yaitu etnis Rohingnya. Isi Resolusi ini mendesak Pemerintah Myanmar untuk segera mengambil langkah-langkah dalam memerangi ujaran kebencian terhadap orang Rohingya dan minoritas lainnya di Rakhine, Kachin dan Shan (tempo.co, 2019).

Setidaknya ada tiga langkah yang dapat diambil oleh PBB dalam mengatasi konflik Rohingnya. Pertama, Peace Making. Peace Making adalah tindakan untuk membawa para pihak yang bersengketa untuk saling sepakat khususnya secara damai. Kedua, Peace Keeping. Peace Keeping adalah tindakan untuk mengerahkan kehadiran PBB dalam memelihara perdamaian dan kesepakatan para pihak yang berkepentingan. Ketiga, Peace Building. Peace Building adalah tindakan untuk mengidentifikasikan dan mendukung struktur-struktur yang ada guna memperkuat perdamaian.

\section{Pelanggaran HAM Terhadap Etnis Rohingya persfektif ASEAN}

Setelah dikritik sejumlah kelompok hak asasi internasional, pemerintah Burma menyatakan minoritas muslim Rohinya „,berhak ${ }^{e e}$ mendaftar untuk mendapatkan kewarganegaraan. Pada tanggal 18 November 2012 dalam ASEAN Submit atau 
konferensi tingkat tinggi ASEAN di Kamboja, kepala negara anggota ASEAN memandatangani Deklarasi HAM ASEAN (ASEAN Human Rights Declaration). Deklarasi diharapkan dapat menyamakan persepsi dan memperbaiki perlindungan hak asasi manusia di kawasan berpenduduk 600 juta tersebut. Selain itu juga diharapkan dapat menjadi standar HAM di negara-negara anggota ASEAN. Negara-negara anggota ASEAN, yaitu Brunei Darussalam, Kamboja, Indonesia, Malaysia, Myanmar, Laos, Thailand, Vietnam, Filipina, dan Singapura, memiliki hukum, sistem pemerintahan, dan kondisi HAM yang berbeda-beda. Dengan adanya deklarasi itu tersebut 10 negara anggota mau tidak mau mereka harus tunduk terhadap Deklarasi HAM ASEAN (Joko Sulistyo;2012).

Salah satu tindakan internasional untuk penegakan HAM adalah Humanitarian Action (Kusuma, 2007:4). Konsep Humanitarian Action dibangun atas prinsip-prinsip dasar yang tercantum dalam Konvensi Jenewa IV, yaitu: prinsip kemanusiaan, netralitas, dan imparsialitas (Srikandi, 2010:2). Dengan melihat semakin kompleksnya permasalahan Rohingnya, etnis tersebut membutuhkan aksi kemanusiaan yang antara lain dapat dilakukan oleh Association of South East Asian Nation (ASEAN) antara lain berupa pemberian bantuan bagi Rohingnya, kerjasama antar negara ASEAN dalam menerima pengungsi Rohingnya, dan rekomendasi kepada pemerintah Myanmar untuk menghormati HAM Rohingnya serta memberikan status kewarganegaraannya (SK, 2011:5).

Terkait dengan prinsip NonIntervensi yang dianut oleh negara-negara angota ASEAN, Myanmar dengan tegas menolak pertolongan ataupun bantuan Negara-negara di ASEAN dalam menyelesaikan kasus intern yang terjadi di negara Myanmar (Rahmanto,2017:148- 150). Hal inilah yang masih menjadi salah satu penghambat upaya pembelaan HAM bagi etnis Rohingnya yang dilakukan oleh berbagai kalangan internasional yang ingin menuntaskan kasus pelanggaran HAM ini, termasuk International Criminal Court (ICC) (Erika, 2014:184)

\section{Upaya Penyelesaian Permasalahan Pelanggaran HAM etnis Rohingya melalui Yurisdiksi International Criminal Court}

Pada tahun 1998, diselenggarakann The United Nations Diplomatic Conference of Plenipotentiaries tentang Pembentukan suatu Mahkamah Pidana Internasional yang berlangsung dari tanggal 15 Juni sampai 17 Juli 1998 di Markas Besar FAO di Roma, 
Itali. Konferensi tersebut dihadiri oleh 160 Negara termasuk Indonesia, 33 Organisasi Internasional dan sebanyak 236 NGO's. Statuta Mahkamah Pidana Internasional tersebut diterima melalui pemungutan suara pada tanggal 17 Juli 1998 oleh 120 Negara, 7 menentang dan 21 abstain (Mauna, 2003:188). Berdasarkan Statuta Roma 1998 tersebut terbentuklah sebuah mahkamah pidana internasional yang bersifat permanen dan independen dan mulai menjalankan fungsinya secara efektif setelah diratifikasi oleh 60 Negara Maka ICC adalah merupakan Pengadilan Pidana Imernasional masa depan, yang bersifat permanen (tetap) dan tidak menerapkan prinsip berlaku surut, sehingga proses peradilannya sesuai dengan prinsip-prinsip umum hukum pidana yang bersifat universal, karena dalam Statuta Roma 1998 telah diatur hukum materinya yang memberikan ancaman hukuman.

Selain dari pada itu karena ICC pembentukannya tidak terkaitkan pada kasus tertentu yang terjadi pada saat dan tempat tertentu, tetapi didasarkan pada pertimbangan kepentingan umat manusia untuk masa depan, dengan asumsi kemungkinan terulangnya lagi kejahatan yang mengancam perdamaian keamanan dan kesejahteraan dunia, maka akan melibatkan partisipasi seluruh (banyak) negara di dunia, yang tentunya didalam proses penyelenggaraan peradilannya diperlukan kerjasama dan untuk kepentingan kerjasama itu diperlukan suatu azas yang menjadi landasan kerjasama antara ICC dengan negara pihak (negara nasional), bahwa azas tersebut dalam statuta disebut complementary principle (asas pelengkap) yang merupakan salah satu azas dasar yang menjiwai berdirinya ICC dimana ICC statusnya dan fungsinya tidak menggantikan pengadilan nasional atau merupakan perluasan dari pengadilan nasional, tetapi justru hanya sekedar melengkapi dalam hal negara nasional (Negara pihak) tidak bersedia (unwilling) atau tidak mampu (unable) mengadili (Martowirono H. S., 2001:346).

ICC dapat melaksanakan kewenangannya atas suatu kasus jika negara yang mempunyai yurisdiksi atas kasus, sungguh-sungguh tidak mau (unwilling) atau tidak mampu (unable) untuk melakukan penyidikan atau penuntutan (Schabas, 2017:10). Ketentuan Pasal 17 ayat (2) Statuta Roma 1998 menjelaskan bahwa ICC dapat melaksanakan yurisdiksi apabila salah satu syaratnya sistem pengadilan nasional suatu negara unwilling. Ketentuan Pasal 17 ayat (3) Statuta Roma 1998 menjelaskan bahwa ICC akan mempertimbangkan indikator (unable) ketidakmampuan. 
Tidak berjalannya sistem hukum nasional Myanmar menjadi salah satu bukti bahwa pemerintah Myanmar tidak mau mengusahakan tindakan penyelesaian terhadap kasus terkait Etnis Rohingnya. Sebagaimana fungsi dari ICC untuk menyelesaikan kasus pelanggaran HAM berat, seharusnya ICC dapat segera menangani kasus tersebut melalui mekanisme keputusan DK PBB mengingat Myanmar bukanlah sebagai negara peratifikasi. Pemerintah Myanmar terkesan menunda penyelesaian kasus etnis Rohingnya karena Etnis Rohingnya bukan warga negara Myanmar meskipun etnis tersebut telah bermukim selama beberapa keturunan di Myanmar(unwiilling). Kondisi sistem peradilan nasional Myanmar yang tidak mampu berfungsi secara optimal dalam menyelesaikan kasus Etnis Rohingnya sekaligus mengadili pelaku pelanggaran HAM berat terhadap Etnis Rohingnya menjadi salah satu bukti pemenuhan indikator ketidakmampuan negara (unable).

Definisi human security yang paling umum diambil dari Human Development Report tahun 1994, secara ringkas UNDP memberikan definisi human security dalam tiga aspek. Aspek yang pertama adalah aspek keamanan dari ancaman-ancaman kronis (chronic threats) seperti kelaparan, penyakit, dan represi. Aspek kedua, perlindungan dari gangguan yang tiba-tiba dan menyakitkan terhadap pola-pola kehidupan seharihari, dan aspek ketiga adalah kebebasan dari rasa takut, ancaman, atau bahaya. Hal ini terutama karena konsep human security berfokus pada menjamin keamanan bagi individu, bukan negara.

Keberadaan Etnis Rohingnya jika dianalisis dengan aspek Human Security (kebebasan dari rasa takut, ancaman, atau bahaya), saat ini banyak Etnis Rohingnya yang keluar dari Myanmar untuk mencari suaka atau menjadi pengungsi. Fenomena pengungsi adalah salah satu gejala yang signifikan dari adanya krisis ketidakamanan manusia karena rumah, barang-barang pribadi dan ikatan keluarga adalah bagian penting dari keamanan semua orang. Setiap negara yang didatangi pengungsi tersebut tidak boleh memulangkan para pengungsi tersebut (non refoulement) (Riyanto, 2016:7).

\section{Kesimpulan}

bentuk kekerasan apapun yang ditujukan kepada etnis Rohingya yang dilakukan oleh Pemerintahan Myanmar tidak dapat dibenarkan apalagi hal tersebut masih dalam lingkup kawasan Asia Tenggara, sebagai suatu negara anggota ASEAN sudah saatnya Myanmar tunduk terhadap Piagam ASEAN yang telah disepakati secara bersama oleh 
sepuluh negara angota ASEAN yang lainnya serta terbentuknya Badan HAM ASEAN digunakan sebagai suatu lecutan untuk meminimalkan pelanggaran HAM yang terjadi di Asia Tenggara.

ICC dapat melaksanakan kewenangannya atas suatu kasus jika negara yang mempunyai yurisdiksi atas kasus, sungguh-sungguh tidak mau (unwilling) atau tidak mampu (unable) untuk melakukan penyidikan atau penuntutan (Schabas, 2017:10). Ketentuan Pasal 17 ayat (2) Statuta Roma 1998 menjelaskan bahwa ICC dapat melaksanakan yurisdiksi apabila salah satu syaratnya sistem pengadilan nasional suatu negara unwilling. Ketentuan Pasal 17 ayat (3) Statuta Roma 1998 menjelaskan bahwa ICC akan mempertimbangkan indikator (unable) ketidakmampuan.

ICC menjalankan yurisdiksinya sebagai bentuk penyelesaian kasus rohingnya yaitu menerapkan 4 yurisdiksinya yaitu, Pertama, Personal Jurisdiction.. Kedua, Material Jurisdiction. Material jurisdiction. Ketiga, Temporal Jurisdiction. . Keempat, Territorial Jurisdiction, (Wahyuni, 2016:4).

Adapun usaha dan upaya penyelesaian sengketa ini yang dilakukan oleh PBB sebagai payung penyelesaian sengketa internasional yaitu melalui resolusi Dewan Keamanan PBB dan Majelis Umum PBB. Namun, dalam kasus krisis Rohingnya di Rakhine, PBB secara kelembagaan hanya mengeluarkan dua kali resolusi.

\section{Daftar Pustaka}

Carlsnaes, Walter.,Thomas Risse., Beth A Simmons. (2013) . Handbook Hubungan Internasional. (terjemahan Imam Baehaqie). Nusa Media : Bandung.

Erika, Dewa Sudika Mangku. (2014). Meneropong prinsip non intervensi yang masih melingkar dalam asean. Jurnal Perspektif, Vol. 19 No. 3

Haryomataram. (1994). Kewenangan Dewan Keamanan PBB Terutama yang Berhubungan dengan Pembentukan dan Pengoperasian Pasukan PBB. Surakarta: Sebelas Maret University Press.

Kusuma, Yeni. (2007). Peran UNICEF atas perlindungan kekerasan seksual terhadap perempuan dalam konflik di republik demokratik kongo (2004-2008)", Jurnal Analisis Hubungan Internasional, Vol. 1 No.1

Martowirono, H. Suwardi. (2001). Hukum Dan Pembangunan: Azas Pelengkap Statuta Roma 1998 tentang ICC.

Rahmanto, Tony Yuri, .(2017). Prinsip non intervensi bagi asean ditinjau dari perspektif hak asasi manusia. Jurnal HAM , Vol 8 No 2. 
Riyanto, Sigit. (2016). Prinsip non refoulement dan relevansinya dalam sistem hukum internasional. Jurnal Mimbar, Vol 22 No 3.

SK, Ayub Torry. (2011). Perlindungan Hak Asasi Manusia Pengungsi Internasional. Jurnal hukum yustisia, Vol 1 No 2 Universitas Sebelas Maret, Surakarta.

Srikandi, Annisa Gita. (2010). Comprehensive security dan Humanitarian Multiversa Action. Jurnal multiversa, Vol 1 No 2.

Sulistyo, Joko .2012. Deklarasi HAM ASEAN: Ada dan Tiada, "Deklarasi HAM ASEAN mengamanatkan standar perlindungan HAM secara universal. VHR media, Rabu.2012.

Supriyadi., Dedi .(2013). Hukum Internasional (dari konsepsi sampai aplikasi). Bandung : CV Pustaka Setia.

Thontowi, Jawahir, 2013. "Perlakuan Pemerintah Myanmar terhadap minoritas muslim RohingnyaPerspektif sejarah dan Hukum Internasional”, Jurnal Pandecta, Fakultas Hukum Universitas Islam Indonesia, Volume 8 No. 1

Liliansa, Dita .(2013). Hak Kewarganegaraan Etnis Rohingya, UNHCR, "Mencegah dan Mengurangi Keadaan Tanpa Kewarganegaraan: Konvensi 1961 tentang Pengurangan Keadaan Tanpa Kewarganegaraan”.

Snyder, H. (2019). Literature review as a research methodology: An overview and guidelines. Journal of Business Research, 104(July), 333-339. https://doi.org/10.1016/j.jbusres.2019.07.039

Wahyuni. (2016). Kejahatan genosida terhadap etnis rohingnya dalam perspektif humaniter dan pertanggungjawaban, Vol. III No.2 